\title{
Emergency Management of Natural Disaster Risk Tourism -- A Case Study of Jiuzhaigou Earthquake
}

\author{
Xuna Han Li Li \\ Pan-Asia Business School, Yunnan Normal University, 650092 Kunming, China
}

\begin{abstract}
The west of China is prone to natural disasters. Natural disasters not only bring huge economic losses to the local people, but also restrict the healthy development of regional national economy. In recent years, with the rapid development of tourism industry in China, the natural disasters in tourism destination are on the rise, and tourism security has become a hot topic.Taking Sichuan Jiuzhaigou as an earthquake case, this paper discusses the emergency management of earthquake disaster risk in tourist attractions.
\end{abstract}

\section{Keywords}

Tourist attraction; Earthquake; Emergency management; Jiuzhai Valley

\section{旅游景区自然灾害风险的应急管理}

一以九寨沟地震为例

\author{
韩旭娜 李丽 \\ 云南师范大学泛亚商学院, 昆明 650092, 中国
}

摘要：我国西部是自然灾害频发地区，自然灾害不仅给当地人民带来巨大经济损失，更制约 了区域国民经济的健康发展。近年来, 我国旅游事业飞速发展, 但旅游目的地自然灾害呈上 升趋势, 旅游安全问题成为采手可热的话题。本文以四川省九寨沟地震为例, 借鉴国外经 验, 从当地政府、游客、景区管理者和当地居民角度, 提出旅游景区地震灾害风险的应急管 理措施。

关键词：旅游景区；地震；应急管理；九寨沟

\section{1. 引言}

自然灾害是由于自然界的异常变 化造成的人员伤亡、财产损失、社会 不稳定、资源遭到破坏的现象或者一 系列事件。在世界范围内，重大的突
发性自然灾害包括: 旱灾、洪涝灾 害、风暴潮、冰雨灾害、地震、火 山、滑坡、泥石流、森林火灾、农林 病害等。中国是世界上自然灾害最严 重的少数国家之一，灾害种类多、发 生频率高、分布地域广、造成损失 大，洪涝、台风、旱灾、冰雨、地震 
等灾害不断发生.特别是上世纪 90 年代 以来, 自然灾害造成的经济损失呈明 显上升趋势, 并且已经成为影响国民 经济发展和社会稳定的重要因素.进入 21 世纪以来, 随着全球气候变暖, 自 然灾害发生的频率日益呈上升趋势, 我国面临的防灾减灾形势更为严峻。

美国学者 Robert Heath 根据危机形 成和发展的生命周期设计提出了缩减 ( reduction)、预备 ( readiness)、反应 ( response)、恢复( recovery) 的危机管 理模型。米托夫和皮尔森提出危机管 理五阶段模型：信号侦测阶段、准备 和预防阶段、损失控制阶段和免疫阶 段.日本学者龙泽正雄认为危机管理是 发现、确认、分析、评估、处理的全 过程.国内学者胡白精提出突发事件应 急管理应划分为事前预警、事中处置 和事后恢复管理三个阶段。魏加宁认 为全过程的应急管理应该包括预测、 预防、应对和免疫四个阶段。李经中 认为应急管理分为监测、预警阶段, 预控预防阶段, 应急处理阶段和评估 恢复阶段。印海延在对灾害应急管理 各种阶段性理论进行分析总结精简之 后将灾害应急管理简化为危机前管理 阶段 (预警、预防、备灾)、危机中管 理阶段( 快速反应、应急处置) 和危机 后管理阶段 (总结、评估、问责) 三个 阶段 [1]。虽然国内有学者结合具体案例 探讨我国自然灾害应急管理制度存在 的问题, 并提出了相应的对策建议, 但是其理论成果仍然停留在宏观层 面, 并不适用解决区域自然灾害应急 管理中存在的问题, 尤其旅游景区中 地震应急管理问题。

本文在以往学者研究成果的基础 上, 借鉴当代国际经验, 并结合 2017 年 8 月 8 日四川九寨沟地震的案例, 探讨提高旅游景区地震灾害应急管理 水平的对策建议. 文章将分为以下几个 部分：一是九寨沟景区的自然条件、 发生地震情况及造成的损失; 二是国
外旅游景区自然灾害应急管理经验; 三是以近期九寨沟地震为中心, 探讨 现行区域旅游景区灾害应急管理中存 在的问题, 并提出相应对策。

\section{2. 九寨沟景区的旅游资源及地震概况}

\section{1. 九寨沟景区旅游资源概况}

九寨沟主沟呈 “Y”字形, 总长 50 余公里, 总面积 64297 公顷, 森林 覆盖率超过 $80 \%$, 沟中分布有多处湖 泊、瀑布群和钙化滩流等.九寨沟地处 青藏高原向四川盆地过渡地带, 地质 背景复杂, 碳酸盐分布广泛, 褶皱断 裂发育, 新构造运动强烈, 地壳抬升 幅度大, 多种营力交错复合, 造就了 多种多样的地貌, 发育了大规模喀斯 特作用的钙化沉积, 以植物喀斯特钙 化沉积为主导。九寨沟国家级自然保 护区主要保护对象是大熊猫、金丝猴 等珍稀动物及自然生态环境, 有 74 种 国家珍稀保护植物, 有 18 种国家珍稀 保护动物, 还有丰富的古生物化石、 古冰川地貌。“九寨归来不看水”, 是对九寨沟景色的真实诠释. 泉、瀑、 河、滩 108 个海子, 构成一个个五彩 斑斓的瑶池玉盆。

\section{2. 九寨沟地震概况}

2017 年 8 月 8 日 21 时发生在九寨 沟的 7.0 级地震, 震中位于九寨沟核心 景区西部 5 公里处比芒村。由于震中 距离核心景区较近, 所以地震给旅游 资源带来巨大破坏, 给游客及当地居 民带来巨大灾难。受地震影响, 九寨 沟部分景区和通往景区的道路受到山 体滑坡的损坏，火花海和诺日朗瀑布 被震坏已不复存在。“西游记”取景 瀑布只能修复, 不可能复原。截至 8 月 13 日 20 时, 地震造成 550 人伤亡, 19768 户 176492 人, 73671 间房屋不同 程度受损, 涉及阿坝州九寨沟、松 
潘、若尔盖、红原等 4 个县 53 个乡 (镇)309 个村(社区)。九寨沟地震共造 成道路交通经济损失约 3704 万元，房 屋经济损失约 860 万元，农业经济损 失约 295101 万元, 林业经济损失约 2150 万元, 通讯经济损失约 200 万 元, 电力经济损失约 180 余万元, 工 业经济损失约 1400 万元。

\section{3. 国外旅游景区应急管理经验}

日本旅游资源丰富，也是地震频 发的国家之一, 为了减少地震的灾害 损失，京东都政府在地震的预测、预 防、应急、救援和恢复重建各个环节 采取了各种措施, 并且从法律制度的 建设、规划编制和实施、防灾的公共 投资建设、教育方面加强防灾管理.为 了汲取阪神大地震的教训, 政府特别 强调先期处置和信息收集, 完善紧急 启动机制。包括职员召集制度和职员 紧急分配制度。京东成立灾害对策指 挥部后, 根据灾情, 发出第一级到第 五级的紧急配备状态的应对命令, 动 员各局、地方队长、及本部的职员出 动。为了应对在晚上或者节假日等下 班时间发生的自然灾害, 京东都设立 了夜间防灾联络室和安排了东京都灾 害应急职员住宅, 确保应急机制正常 运行。

美国的自然灾害应急响应框架采 用国家一州政府一市政府三级管理体 制, 应急救援一般遵循属地原则和分 级响应原则。自然灾害应急管理具体 由联邦紧急事务管理局(FEMA) 负责总 指挥, FEMA 在全国设立了 10 个应急 管理分局.美国自然灾害应急管理措施 具体分为减灾措施一灾前准备一应急 响应一灾后重建 4 个环节, 旅游景区 发生自然灾害时, 由联邦紧急事务管 理局指挥紧急救援事项。

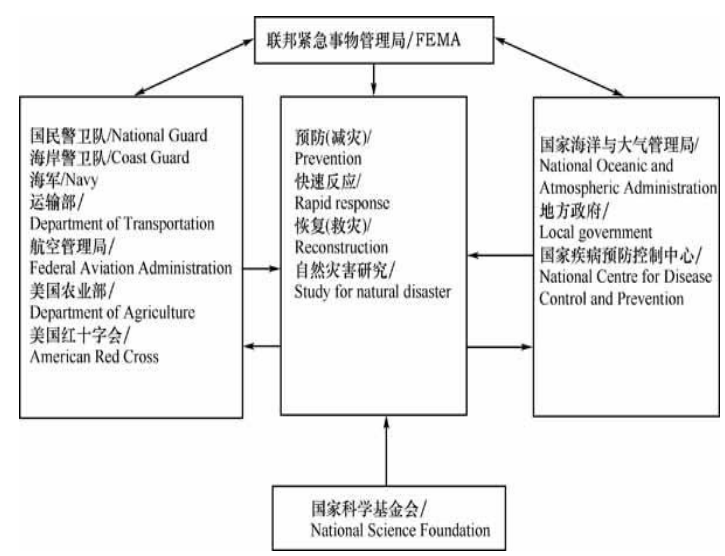

图 1：美国自然灾害应急响应框架

澳大利亚设立了一套三个层次承 担不同职责的政府应急管理体系：联 邦政府——州和地方政府——社区, 三个层面各司其责，互相配合 ${ }^{[2]}$ 。

泰国的灾害体制大体分为国家、 曼谷市（县）以及特别市（郡） 3 个层 级.目前泰国已经形成以防灾减灾法律 为依托, 内阁总理为最高指挥官, 内 政部负责整体协调和联络, 通过国家 防灾减灾委员会等决策机构指定应急 方案, 由防灾减灾厅、气象局、国家 灌溉局、农业和合作社部、水力资源 局、天然资源和环境部等部门负责具 体实施的国家灾害管理体制 ${ }^{[3]}$ 。

\section{4.我国旅游景区地震灾害应急管理对策 建议}

旅游景区的地震灾害应急管理包 括事前预防、事发应对、事中处置和 善后恢复四个阶段。近年来, 我国旅 游景区发生自然灾害频繁, 造成的损 失巨大。由于国内学者对旅游景区的 地震灾害风险管理做了大量研究, 所 以本文仅按利益相关主体分类讨论旅 游景区地震发生时应该如何应对, 如 何进行灾后恢复与重建。 


\section{1. 当地政府的角度}

（1）在旅游景区, 当地震灾害发 生时, 政府首先要任务是搜集灾情信 息, 从景区管理当局了解景区游客数 量, 以及景区游客的集中区域, 景区 地质脆弱区域. 其次启动应急响应机 制, 组织救援。

（2）在组织救援过程中，政府应 组织专门机构, 就灾害发生地的脆弱 性进行分析, 考虑社会抗震救灾力量 以及抗震救灾物资车辆的进入是否会 加重环境负担。

（3）当地政府在救灾过程中加大 资金投入，对灾区情况实时监测，确 保抗震救灾工作能顺利进行, 挽救不 必要的损失。

（4）组织地质专家进入灾区，对 当地地质情况进行严密分析, 实施预 报气象情况, 避免在救灾过程中发生 二次灾害。

（5）旅游景区灾后重建过程中, 政府要加大资金投入，全力挽救当地 资源，尽量减少损失. 由于旅游自然资 源的不可再生性, 要完全恢复几乎不 可能, 所以政府可以建立地震灾害遗 址, 让更多游客了解原来景象。

(6) 政府要充分发挥在景区震后 的危机公关作用.当旅游景区发生自然 灾害后, 旅游者处于自身生命安全的 考虑, 对灾后重建的旅游景点或者附 近景点的游览欲望降低. 受九寨沟地震 影响, 黄龙景区 “十一黄金周” 仅接 待游客 12777 人次，较去年同期下降 $87.43 \%$. 所以政府在建立景区安全机制 的基础上, 加大宣传力度, 吸引更多 的游客。

(7) 组织旅游景区的交通建设。 旅游景区一般远离城镇人口密集区, 交通不发达, 随着自驾游的兴起, 越 来越多私家车的驶入给景区交通带来 巨大压力。地震发生时, 行驶在路上
的游客根本没有可能躲避灾害, 所以 旅游景区交通体系建设势在必行。

\section{2. 游客的角度}

(1) 出行前分析旅游景区的灾 害危险系数, 做好应急储备, 包括食 品、饮用水、御寒的衣物等。

（2）到达旅游景区后, 首先要了 解居住环境, 排查居住地的安全隐 患, 了解周围的地质构造, 注意收听 最新的气象预报。尤其山地景区, 发 生大雨预报时, 要做好紧急撤离准备. 大雨通常可能会带来次生滑坡、泥石 流危害, 严重威胁自身安全。

（3）地震发生时，要保持镇静, 采取科学的应对措施。若不能立即逃 离, 首先要寻找紧急避难场所, 等待 救援。

\section{3.旅游景区管理者角度}

(1) 旅游景区管理者担负着游客 生命安全的重任, 所以无论景区的酒 店还是供参观的建筑物都要有最高抗 震等级, 一旦发生地震, 尽量减少人 员伤亡。

（2）做好地震灾害宣传教育。随 着旅游群体的扩大, 老人和儿童的比 例不断上升，老人和儿童的危险感知 程度较差. 进行地震灾害宣传教育, 确 保地震发生时都能自救。

（3）组织防灾应急演练。无论自 驾游还是跟团游的旅客, 到达景区 后, 景区管理者应组织防灾应急演 练, 以便灾害发生时能够有序组织人 员撤离, 减少人员伤亡。

（4）建立应急避难场所。九寨沟 景区自然条件复杂, 历史上曾多次发 生过滑坡、泥石流等自然灾害, 给游 客、当地居民及生态环境带来巨大损 失, 是我国自然灾害较频繁的景区之 一。因此, 建立应急避难场所, 便于灾 
害发生时政府组织紧急救援, 减少灾 害给游客及当地居民带来的损失。

（5）灾害发生时，景区管理者应 积极配合当地政府的紧急救援工作; 给政府提供最详细的游客信息及灾害 发生地点、造成的损失等信息, 以便 政府有重点、有秩序组织救援工作。

\section{4. 当地居民的角度}

(1) 自发有序组织旅游景点自然 灾害紧急应对方法的宣传;

（2）保护当地生态环境;

(3) 培养较强的危机意识;

(4) 积极配合政府的组织救援工

作;

（5）建设居民住宅时, 要考虑灾 害风险, 建立防震等级更高的房屋。

\section{致谢}

本文获得云南省科技计划面上项 目（2017FB103），云南省哲学社会科 学规划项目(YB2016016), 云南省教育 厅科学研究基金项目(2016ZZX080), 云南师范大学博士科研启动项目, 云 南师范大学 “登峰扎根” 优秀科研创 新团队建设项目，云南省泛亚金融合 作发展促进会博士后科研基金项目, 昆明学院科学研究项目 (XJZZ1617) 的资助。

\section{参考文献}

[1] 侯俊东, 李铭泽自然灾害应急管理 研究综述与展望 $[\mathrm{J}]$ 防灾科技学院学 报，15(1): 48-55,2013.

[2] 梁永朵, 王艳, 黄祖超等国外自然 灾害应急管理体系对我国应急管理 工作的启示 $[\mathrm{J}]$ 防灾科技学院学报, 11(3): 130-132,2009.

[3] 王德讯泰国灾害管理体制研究 $[\mathrm{J}]$ 东 南亚纵横, 9(9): 28-32,2014. 